2015

\title{
Innocence at Stake: Possibility of DNA Collection from Arrestees in Canada
}

Washim Ahmed

Follow this and additional works at: http://digitalcommons.osgoode.yorku.ca/olsrps

\section{Recommended Citation}

Ahmed, Washim, "Innocence at Stake: Possibility of DNA Collection from Arrestees in Canada" (2015). Osgoode Legal Studies Research Paper Series. 89.

http://digitalcommons.osgoode.yorku.ca/olsrps/89 


\section{OSGOODE HALL LAW SCHOOL LEGAL STUDIES RESEARCH PAPER SERIES}

Research Paper No. 09

Vol. 10/ Issue. 02/ (2015)

\section{Innocence at Stake: Possibility of DNA Collection from Arrestees in Canada}

Washim Ahmed

\section{Editors:}

Editor-in-Chief: Carys J. Craig (Associate Dean of Research \& Institutional Relations and Associate Professor, Osgoode Hall Law School, York University, Toronto)

Production Editor: James Singh (Osgoode Hall Law School, York University, Toronto)

This paper can be downloaded free of charge from: http://ssrn.com/abstract=2543749

Further information and a collection of publications from the Osgoode Hall Law School Legal Studies Research Paper Series can be found at:

http://papers.ssrn.com/sol//JELJOUR_Results.cfm?form_name=journalbrowse\&journal_id=722488

Osgoode Legal Studies Research Paper No. 09 
Vol. 10/ Issue. 02/ (2015)

\title{
Innocence at Stake: Possibility of DNA Collection from Arrestees in Canada
}

\author{
Washim Ahmed
}

\begin{abstract}
:
Followed by a decision of the Supreme Court of the United States, which approved the collection of a defendant's DNA upon arrests under the Fourth Amendment, the Minister of Justice, Peter MacKay indicated in an interview with the Globe and Mail that he and his Ministry are considering a similar model for Canada.

This paper examines the possibility of a similar legislative framework in Canada and argues that although collection of DNA upon arrests was found justified under the Fourth Amendment, it does not necessarily mean that it will be found justified under the Canadian Charter of Rights and Freedoms. While s.8 of the Charter seems to give similar protection as the Fourth Amendment, they have very different requirements for judicial authorization, reasonableness and standard of probable cause.
\end{abstract}

Scrutinizing those different requirements and standards, this paper holds that the process of DNA collection is highly intrusive and would be a serious violation of s. 8 of the Charter as it could reveal an excessive amount of private information about an individual over which he/she has a strong reasonable expectation of privacy. Furthermore, it will deprive people from their right to be presumed innocent, which is protected under s.11 (d) and significantly impact socially marginalized groups.

Finally, this paper conducts an analysis of the violations under s.1 of the Charter and indicates that none of the violations can be justified in a free and democratic society.

\section{Keywords:}

criminal law, DNA, collection, constitutional law, admin law, human rights, charter, s.8, s.11 (d), innocence, presumption, reasonable doubt, threats, maryland, king, us, supreme court, biographical core information, privacy, reasonable expectation, search, seizure, justification, fingerprint

\author{
Author(s): \\ Washim Ahmed \\ Osgoode Hall Law School \\ York University, Toronto \\ E: mdahmed@osgoode.yorku.ca
}




\section{Innocence at Stake: \\ Possibility of DNA Collection from Arrestees in Canada}

Md Washim Ahmed

\section{ABSTRACT}

Followed by a decision of the Supreme Court of the United States, which approved the collection of a defendant's DNA upon arrests under the Fourth Amendment, the Minister of Justice, Peter MacKay indicated in an interview with the Globe and Mail that he and his Ministry are considering a similar model for Canada.

This paper examines the possibility of a similar legislative framework in Canada and argues that although collection of DNA upon arrests was found justified under the Fourth Amendment, it does not necessarily mean that it will be found justified under the Canadian Charter of Rights and Freedoms. While s. 8 of the Charter seems to give similar protection as the Fourth Amendment, they have very different requirements for judicial authorization, reasonableness and standard of "probable cause".

Scrutinizing those different requirements and standards, this paper holds that the process of DNA collection is highly intrusive and would be a serious violation of s.8 of the Charter as it could reveal an excessive amount of private information about an individual over which he/she has a strong reasonable expectation of privacy. Furthermore, it will deprive people from their right to be presumed innocent, which is protected under s.11 (d) and significantly impact socially marginalized groups.

Finally, this paper conducts an analysis of the violations under s. 1 of the Charter and indicates that none of the violations can be justified in a free and democratic society. 


\section{INTRODUCTION:}

In a recent judgment, the Supreme Court of the United States approved the collection of a defendant's DNA upon arrests under the Fourth Amendment. ${ }^{1}$ Interestingly, it seems that Canadian legislatures found this decision very inspiring as the Minister of Justice, Peter MacKay expressed in an interview with the Globe and Mail that he and his Ministry are considering a similar model for Canada. Historically, Canada has been under the influence of American legal developments since the day the first Canadian Criminal Code was enacted. ${ }^{2}$ Therefore, it will not be surprising if Canada adopts a similar model despite the fact that some criminal defense lawyers and civil liberty advocates already warned the governments about its potential constitutional invalidity and its violation of individual's rights and freedom. ${ }^{3}$

While the Supreme Court of the United States finds collecting DNA from arrestees is reasonable under the Fourth Amendment, which protects individuals from "unreasonable searches and seizures", it does not necessarily mean that it may be found reasonable under the Canadian Charter of Rights and Freedom. ${ }^{4}$ There are two provisions of the Charter that could be infringed if such an approach is adopted - (i) right to be secure against unreasonable search or seizure under s. 8; and (ii) presumptions of innocence under s.11 (d). It is important to note that

\footnotetext{
${ }^{1}$ Maryland $v$ King, [2013] US LEXIS 4165 at 3-28.

${ }^{2}$ Polygamy was added to Canadian criminal code under the influence of American legislature in the first Canadian Criminal Code in 1889 despite the fact that there was no polygamist in Canada on that time. See, Washim Ahmed, "Criminalization of Polygamy in Canada: Historical, Legal and Sociological Analysis" (2014), 10 Osgoode Legal Studies Research Paper Series 78, online: Social Science and Research Network $<$ http://ssrn.com/abstract $=2508804>$.es

${ }^{3}$ Kim Mackrael, "Feds looks at plan to collect DNA from suspects upon arrestl, The Glove and Mail (2 October 2013) online: http://www.theglobeandmail.com/news/politics/ottawa-looks-at-plan-to-collect-dna-from-suspects-uponarrest/article14652881/.

${ }^{4}$ Canadian Charter of Rights and Freedoms, Part I of therConstitution Act, 1982, being Schedule B to the Canadag Schedul anadag Schedule B to thebe referred as the Charter too].
} 
although s. 8 of the Charter seems to give similar protection as the Fourth Amendment, they have very different requirements for judicial authorization, reasonableness and standard of probable cause. ${ }^{5}$ This paper scrutinizes those different requirements and standards ${ }^{6}$ and holds the view that the process of DNA collection is highly intrusive as it could reveal an excessive amount of private information about an individual over which he/she has a strong reasonable expectation of privacy. In essence, DNA collection from arrestees will be a serious violation of s. 8 of the Charter. Furthermore, it will deprive people from their right to be presumed innocent, which is protected under s.11 (d).

In doing so, this essay is divided into three parts. Part I gives an overview of the various requirements of s. 8 of the Charter and analyzes whether collecting DNA from arrestees could meet those requirements. Part II describes the idea of the presumption of innocence and demonstrates how individuals will be deprived of this right if their DNA is collected upon arrests. Finally, part III examines whether any of those violation could be justified in a free and democratic society under s.1 of the Charter.

\section{PART I - VIOLATION OF S.8:}

In R. v. Rao, a reference was made to the Ontario Court of Appeal to determine whether a provision of the Narcotic Control Act is "reasonable" within the meaning of s. 8 of the Charter. As a response, the court indicates that there are two grounds based on which a challenge to the

\footnotetext{
${ }^{5}$ Peter Hogg, Constitutional Law of Canada, loose-leaf (Toronto: Carswell, 2006) at 48-3.

${ }^{6}$ An important point should be noted that this paper does not go onto comparing the requirements of the Fourth Amendment and s. 8 because this is beyond its scope. Therefore, it will only focus on the requirements of s. 8 and 11 (d). Also, it is virtually impossible to assess the actual implication and the gravity of the infringements in absence of a specific wording of the Criminal Code. Thus, this paper is written primarily based on different probabilities and certain assumptions will be made accordingly.
} 
reasonableness of a particular search may be made under s.8 of the Charter - firstly, the constitutionality of the legislation that authorizes the search; secondly, the reasonableness of the search itself that was carried out under a constitutionally valid statute. ${ }^{7}$ This essay will examine both - the constitutionality of a potential legislation that would authorize DNA collection and the reasonableness of a search that would involve DNA collection. However, before going to this examination, it is important to determine whether collection of DNA could be considered as a search under the meaning of $\mathrm{s.8}$ and whether a reasonable expectation of privacy exists with respect to collecting DNA from arrestees.

\section{What is a search or a seizure under $5.8 ?$}

A search, under s.8, is defined as “an examination...of a person's person or property in order to look for evidence" and a seizure is taking away anything by the agents of the state in order to use it for evidence. ${ }^{8}$ While both search and seizure are protected under s. 8 , it only protects the person not the property. ${ }^{9}$ Collecting DNA from arrestees clearly falls within the definition of search and seizure under s.8 as it involves examining a person's bodily sample and seizing it for the purpose of law enforcement. Moreover, it is also evident from the Ontario Court of Appeal`s decision in $R v$. Alderton that a search incidental to a lawful arrest can include taking samples of an accusedus hair. ${ }^{10}$

\footnotetext{
${ }_{8}^{7} R v$ Rao (1984), 46 OR (2d) 80 (CA) at 90.

${ }^{8}$ Hogg supra note 5 at $48-4$.

${ }^{9}$ Ibid.

${ }^{10} R v$ Alderton, [1985] 49 OR (2d) 257 (CA).
} 
What is a reasonable expectation of privacy and does it involve in DNA Collection?

There is no exhaustive definition of privacy. Binnie J. describes it as a "protean concept" ${ }^{\prime 11}$ because it evolves over time. The Supreme Court of Canada has recognized that an individual possess three distinct privacy interests - personal privacy, territorial privacy and informational privacy. Personal privacy involves the bodily integrity of a person; the right not to have our bodies touched or explored to disclose objects or matters we wish to conceal. ${ }^{12}$ Territorial privacy goes "beyond our bodies and the places where we live and work". ${ }^{13}$ Informational privacy includes ched or explored to disclose oups, or institutions to determine for themselves when, how, and to what extent information about them is communicated to others". ${ }^{14}$

In Canada, privacy right is protected under the Canadian Charter of Rights and Freedom. Section 8 of the Charter provides everyone the right to be secured against unreasonable search and seizure. Section 8 plays an extremely important role in criminal law context. It protects reasonable expectation of privacy of an accused and imposes a requirement of reasonableness on the law enforcement and other governmental agencies in terms of the techniques and procedures that they can use in obtaining information about an alleged offender or crime. ${ }^{15}$ Any evidence collected without respecting the reasonable expectation of privacy of an alleged offender may be excluded by the virtue of s.24 (2) of the Charter. However, it should be noted that not all violations of privacy are protected under s. 8 . Canadian courts have indicated that s. 8 does not necessarily immune someone from all searches and seizures but only from those that are

\footnotetext{
${ }^{11} R v$ Tessling [2004] 3 SCR 432.

${ }^{12}$ Ibid at $19-23$.

${ }^{13} \mathrm{Ibid}$.

${ }^{14}$ Ibid.

${ }^{15}$ Hogg supra note 5 at $48-2$.
} 
unreasonable. The courts further indicate that the question of whether an intrusion is unjustified is highly contextual and a balanced approach must be taken to mitigate the cost of breaching privacy rights and government's interest in the administration of justice. ${ }^{16}$ However, the courts suggest no single test for the determination of the existence and infringements of someone inreasonable expectation of privacy. Rather, the court takes a "Totality of the Circumstances" 17 approach and indicates that such a determination should be made based on the circumstance of the case at hand. ${ }^{18}$

In $R v$. Plant, based on a number of contextual factors, Sopinka J. sets out a framework to determine the existence of a person's reasonable expectation of privacy. He states,

Consideration of such factors as the nature of the information itself, the nature of the relationship between the party releasing the information and the party claiming its confidentiality, the place where the information was obtained, the manner in which it was obtained and the seriousness of the crime being investigated allow for a balancing of the societal interests in protecting individual dignity, integrity and autonomy with effective law enforcement. [emphasis added] ${ }^{19}$

According to the Plant's factors, first and foremost, the nature of the DNA information and individuals' claim over it should be examined in order to determine the existence of a reasonable expectation of privacy.

\footnotetext{
${ }^{16}$ Hunter $v$ Southam Inc, [1984] 2 SCR 145 at 159-160.

${ }^{17}$ Tessling supra note 11.

${ }^{18}$ It should be noted that it is possible to determine the existence of privacy interests and reasonableness of a search applying only Tessling Test. However, instead of relying entirely on Tessling, this essay uses different tests that were conducted in different circumstances to break down the specific and relevant legal issues and provide a clear and comprehensive legal analysis. Also there are some overleaps betweens various factors of those different tests, but this essay will identify the points of repetition and avoid them accordingly.

${ }^{19} R v$ Plant, [1993] 3 SCR 281.
} 
DNA or deoxyribonucleic acid has been described as the "building block of life" which is found in all the cells of a human body. ${ }^{20}$ Usually, when a bodily substance is left at a crime scene, it is collected and analyzed to create a DNA profile that can be matched against a substance taken from a suspect. ${ }^{21}$ A single DNA can provide unique patterns of information that can be compared between DNA artifacts and samples to confirm or exonerate a suspect. The analytical technique of matching or comparing DNA samples is based on fundamental principles of human genetics. ${ }^{22}$

Genetic uniqueness is a fact of life. From generation to generation, characteristics are inherited, combined, assorted, and reassorted among individuals through a common denominator: the chemical deoxyribonucleic acid, or DNA. And, except in the case of identical twins, no two humans share the same DNA sequence. ${ }^{23}$

The samples collected from criminal suspects have the potential to reveal everything about an individual's genetic makeup including core biological traits, family tree and familial relationships, height, hair color, skin-color and vulnerability to certain diseases. ${ }^{24}$ Science has not yet been able to determine the limits of the amount of information that can be collected from DNA but has confirmed that it could provide clues to behaviour, intelligence, and other core biographical information about an individual. ${ }^{25}$ No two human beings can have similar DNA

\footnotetext{
${ }^{20}$ Canada, Solicitor-General of Canada, Establishing a National DNA Data Bank (Consultation Paper) (Ottawa: Ministry of Supply and Services, 1996) at 2 [hereinafter DNA Data Bank (Consultation Paper)]. See also FW Drobner, "DNA Dragnets: Constitutional Aspects of Mass DNA Identification Testing" (2000), 28 Cap UL Rev 479 at 479 .

${ }^{21}$ MJ Markett, "Genetic Diaries: An Analysis of Privacy Protection in DNA Data Banks" (1996), 42 Case W Res L Rev 635.

${ }^{22}$ US Congress, Office of Technology Assessment, Genetic Witness: Forensic Uses of DNA Tests, OTA-BA-438 (Washington, D.C.: U.S. Government Printing Office, July 1990) at 3.

${ }^{23}$ Ibid.

${ }^{24}$ PL Bereano, "The Impact of DNA-based Identification Systems on Civil Liberties" in Billings, ed DNA on Trial: Genetic Identification and Criminal Justice (New York: Cold Spring Harbor Laboratory Press, 1992) at 123.

${ }^{25}$ ET Juengst, "I-DNA-fication, Personal Privacy, and Social Justice" (1999), 75 Chi-Kent L Rev 61 at 64.
} 
pattern, and the information that DNA can provide is so profound and accurate that it led many commentators to equate DNA typing with fingerprinting. ${ }^{26}$

While DNA information could be extremely helpful for the criminal justice system, it could also reveal excessive amount of private information about an individual over which the person has a strong reasonable expectation of privacy. As the Supreme Court of Canada said in $R$ v. Plant, an individual enjoys a reasonable expectation of privacy with respect to his or her core biographical personal information held by others if the information seized is of a "personal and confidential" nature. Section 8 of the Charter "should seek to protect a biographical core of personal information which individuals in a free and democratic society would wish to maintain and control from dissemination to the state. This would include information which tends to reveal intimate details of the lifestyle and personal choices of the individual". ${ }^{27}$

Moreover, the fact that DNA is a part of an individual's bodily substance, a person has the highest claim of ownership and control over it. This control and ownership reinforces a strong reasonable expectation of privacy as mentioned in $R v$. Belnavis. ${ }^{28}$ However, the court also clarified that the idea of the right to privacy is not necessarily tied to property, but rather the basic requirement of individual freedom obliges the state to respect the dignity, autonomy and integrity of the individual. ${ }^{29}$ The degree of privacy, which the law protects, is closely linked to the effect that a breach of that privacy would have on the freedom and dignity of the individual. Therefore, a person is entitled to an extremely high expectation of privacy in relation to his or

\footnotetext{
${ }^{26}$ Julianne Parfett, "rfett, arfett, , and Social Justice" (1999), 75 Chi-K, (2002) 29 Man LJ 33 at 2.

${ }^{27}$ Plant supra note 19 at 293.

${ }^{28} R v$ Belnavis, [1997] 3 SCR 341. [In this case, the court found that Ms. Belnavis had the right to privacy because the car was in her control, she was legally entitled to drive it and had ownership of the contents searched by the police. However, the court rejected the right to privacy of the passengers because they had no control or ownership over the car or the contents under search].

${ }^{29}$ Ibid.
} 
her bodily integrity ${ }^{30}$ or residence ${ }^{31}$ and entitled to a lesser expectation in relation to a vehicle in which he or she is merely a passenger, ${ }^{32}$ or an apartment to which he or she is a visitor. ${ }^{33}$

\section{Does collection of DNA from arrestees constitute a violate s. 8 of the Charter?}

Since the nature of the DNA and the information that it can reveal are so personal to an individual, collecting such information without any consent or judicial authorization would be a clear deprivation of an individual's right to reasonable expectation of privacy. The decisions in Belnavis and Hunter clearly suggest that a warrantless search not pursuant to any statute is always unconstitutional and unjustified. ${ }^{34}$ In $R$. v. Belnavis, relying on previous circumstantial tests outlined by the Supreme Court of Canada in different cases, the Ontario Court of Appeal held that a warrantless search is presumed to be unreasonable unless it complies with three requirements of reasonableness: (a) the search must be authorized by a statute or common law; (b) the statute that authorizes the search must be reasonable; and (c) the manner in which the search was carried out must be reasonable..$^{35}$

Assuming that the DNA collection from an arrestee will be authorized by the DNA Identification Act, the remaining key determinative factors pursuant to this test are reasonableness of the statute and the reasonableness of the manner of collection. The factors that qualify reasonableness of a statute, which involves someone's right to privacy, were articulated in Hunter v. Southam. In Hunter, the Supreme Court of Canada found the Combines

\footnotetext{
${ }^{30} R v$ Stillman, [1997] 1 SCR 607.

${ }^{31} R v$ Feeney, [1997] 2 SCR 117.

${ }^{32}$ Belnavis supra 28.

${ }^{33}$ R28.avis 2 [1996] 1 SCR 128.

${ }^{34}$ Hogg supra note 5 at $48-26$.

${ }^{35}$ Belnavis supra note 28 at 13.
} 
Investigation Act contrary to s. 8 of the Charter because it did not include three requirements of reasonableness. The court held that in order for a search mandated by a statute to be reasonable, the statute must stipulate: (1) a requirement of a warrant obtained prior to the commission of the search; (2) a requirement of an arbiter "capable of acting judicially" and not involved in the investigation; and (3) a requirement of "reasonable and probable grounds" sworn under oath.

In applying the Hunter factors to the idea of DNA collection, it can be assumed that like the American DNA Fingerprint Act, ${ }^{36}$ there will be no requirement to obtain a warrant prior to the collection of DNA since most of the arrests happen incidentally. The current DNA Identification $\mathrm{Act}^{37}$ also does not require a warrant to be issued in order to collect DNA samples from convicted criminals. Since there would be no requirement of a warrant; there would be no requirements of an impartial arbiter and reasonable and probable grounds sworn under oath. Therefore, further analysis of these factors is redundant and it becomes evident that collecting DNA from arrestees would not meet the requirements of reasonableness set out in the Hunter case.

While it is clear that a statute, which does not require a warrant prior to a search, is unconstitutional, it should be noted that the Supreme Court of Canada, instead of striking down legislations, uses the remedy of "reading down" to limit the provisions to accommodate exigent situation in which a warrant would be impracticable. ${ }^{38}$ This exception necessitates an examination of reasonableness of a search and seizure without a warrant, supported by a statute but fails to meet the Hunter criteria. An analysis of this kind would be the most appropriate in the context of DNA collection from arrestees.

\footnotetext{
${ }^{36}$ DNA Fingerprint Act, 42 US Code $\$ 214135$ a.

${ }^{37}$ DNA Identification Act, SC SCIdentifi

${ }^{38}$ Hogg supra note 5 at 48-25; also see, $R$ v Grants, [2009] 2 SCR 353.
} 
The most comprehensive test to determine the reasonableness of a search without a warrant but mandated by a statute can be found in $R v$. Tessling, in which the Supreme Court of Canada was asked to determine whether the reasonable expectation of the privacy of Mr. Tessling was violated by an FLIR image taken by RCMP without prior judicial authorization. In answering the question and determining the respondent's reasonable expectation of privacy, the court used the "Totality of the Circumstances" test. ${ }^{39}$ The Tessling test follows:

1. What was the subject matter of the DNA information?

2. Did the respondent have a direct interest in the subject matter of the DNA information?

3. Did the respondent have a subjective expectation of privacy in the subject matter of the DNA information?

4. If so, was the expectation objectively reasonable? In this respect, regard must be had to:

a. the place where the alleged "search" occurred;

b. whether the subject matter was in public view;

c. whether the subject matter had been abandoned;

d. whether the information was already in the hands of third parties; if so, was it subject to an obligation of confidentiality?

e. whether the police technique was intrusive in relation to the privacy interest;

f. whether the use of DNA analysis technology was itself objectively unreasonable;

g. whether the DNA profile exposed any intimate details of the respondent's lifestyle, or information of a biographical nature.

Since, first three of the four prongs of the Tessling test and the factor $(\mathrm{g})$ of the $4^{\text {th }}$ prong (objective reasonableness) were discussed earlier in determining the existence of a reasonable expectation of privacy, instead of being repetitive, this analysis will only focus on the other

\footnotetext{
${ }^{39}$ Point to be noted that to make this test more relevant to the discussion of this paper, the word "FLIR" is replaced with "DNA" and "surveillance" was replaced with "DNA analysis technology".
} 
factors of the objective reasonableness test of a search and seizure that involves collection of DNA.

The place where a search occurs plays an extremely important role in respect to its reasonableness. In R.v. Stillman, ${ }^{40}$ an accused under custody, informed the police through his lawyers that he would not consent to the taking of any samples of his bodily fluids. The police were aware of his decision but nevertheless took possession of the tissue discarded by the accused while he was in custody. The Supreme Court of Canada states that although the accused's expectation of privacy in this instance was lower, after his arrest, it was not so low as to permit the seizure of the tissue that contains his bodily substance. The privacy expectation should not be reduced to such an extent as to justify seizures of bodily samples without consent, particularly for those who are detained while they are still presumed to be innocent. ${ }^{41}$ However, this may be different if the accused voluntarily abandons any bodily fluids because in the same case, the court held that the accused had no reasonable expectation of privacy on the mucus that he had thrown away using a tissue paper.

Applying these factors to the idea of DNA collection upon arrests, it could be concluded that such an attempt fails to comply with the aforementioned factors and is considered unreasonable unless an arrestee voluntarily provides his or her DNA samples. It should be noted that while in Stillman the court finds it reasonable to collect the abandoned samples of an arrestee, it might not be the case now because of the factor 4(d) of the Tessling test. It can be argued that if Stillman was decided today, factor 4(d) of the Tessling test would restrict the

\footnotetext{
${ }^{40}$ Stillman supra note 30.

${ }^{41}$ Ibid.
} 
collection of abandoned bodily samples because they can be considered as confidential information held by a third party. Therefore, the only way DNA samples could be collected without a warrant is through voluntarily submission by the accused.

The remaining factors and probably the most serious factors of this test are 4(e) and 4(f). Under the current Canadian Criminal Code, a DNA warrant can authorize one of the three investigative procedures for the collection of biological evidence from a suspect - (1) the plucking of individual hairs, including the root sheath; ${ }^{42}(2)$ the taking of buccal swabs by swabbing the lips, tongue, and inside cheeks of the mouth to collect epithelial cells; ${ }^{43}$ or (3) the taking of blood by pricking the skin surface with a sterile lancet. ${ }^{44}$ All of these methods are highly intrusive and unreasonable because an intrusion into an arrestee's body to obtain a DNA sample cannot be considered minimal. The Supreme Court of the United States in Maryland v. King found the intrusion minimal because of the quickness of the DNA test and the lack of pain experienced by the arrestee during the test. ${ }^{45}$ On the other hand, it has been argued in contrary that the test itself may be quick and painless, but it cannot be minimally intrusive when it involves a governmental authority forcibly sticking a foreign object into a person's mouth without his or her consent. ${ }^{46}$

While the American court finds such DNA collection technique and analysis reasonable, the Supreme Court of Canada seems to take a very different approach. The court held in $R v$. Pohoretsky that the issue of taking blood samples for law enforcement purposes is "a violation of the sanctity of a person's body [that] is much more serious than that of his office or even of his

\footnotetext{
${ }^{42}$ Section 487.06(1)(a).

${ }^{43}$ Section 487.06(1)(b).

${ }^{44}$ Section 487.06(1)(c).

${ }^{45}$ Brian Clark Stuart, "Dethroning King: Why the Warrantless DNA Testing of Arrestees Should Be Prohibited Under State Constitutions (2014) 88 Missisipi LJ 1111 at 1135.

${ }^{46}$ Ibid.
} 
home." ${ }^{47}$ This theme has been picked up in subsequent cases as well. In the context of DNA samples, the court states:

The taking of the dental impressions, hair samples and buccal swabs from the accused also contravened the appellant's s. 7 Charter right to security of the person. The taking of the bodily samples was highly intrusive. It violated the sanctity of the body which is essential to the maintenance of human dignity. It was the ultimate invasion of the appellant's privacy. ${ }^{48}$

Furthermore, in Stillman, the court also equates unauthorized use of a person's body or bodily substances with compelled "testimony" that could render a trial unfair. Based on this reasoning, the court held that the security of the body is as worthy of protection from state intrusion aimed at compelled self-incrimination as are statements. ${ }^{49}$ Therefore, it becomes clear that both police techniques of DNA collection and its analysis both are highly intrusive and unreasonable.

PART II: VIOLATION OF S. 11 (D)

The criminal justice system attempts to provide a normative basis for drawing an appropriate line between the state and individual interests through adopting certain legal doctrines such as the reasonable expectation of privacy, arbitrary detention, and principles of fundamental justice. However, one of the most celebrated legal doctrines in maintaining this balance is the presumption of innocence.$^{50}$ This conception is constitutionally protected by the virtue of s. 11(d) of the Charter as it gives everyone the right "to be presumed innocent until

\footnotetext{
${ }^{47} R v$ Pohoretsky [1987] 1 SCR 945 at 5.

${ }^{48}$ Stillman supra note 30.

49 Ibid.

${ }^{50}$ Thomas A Cromwell, "Proving Guilt: The Presumption of Innocence and the Canadian Charter of Rights and Freedoms" in William H. Charles, Thomas A Cromwell \& Keith B Jobson eds, Evidence and the Charter of Rights and Freedoms (Toronto: Butterworths, 1989) at 125.
} 
proven guilty according to law in a fair and public hearing by an independent and impartial tribunal."

The Supreme Court of Canada has emphasized in many decisions that the presumption of innocence has an omnipresent status in the criminal justice system and protects citizens at the pre-charge stage, ${ }^{51}$ which embraces a normative commitment to the view that all citizens are entitled to be presumed legally and factually innocent of a crime until they are legally and factually proven to be guilty. ${ }^{52}$ In a historic decision, $R v$. Oakes, the Supreme Court of Canada describes the presumption of innocence as something that "protects the fundamental liberty and human dignity of any and every person accused by the State of criminal conduct," and further states that the presumption of innocence is essential in a society committed to fairness and social justice. $^{53}$

The idea "beyond reasonable doubt", which is derived from this notion of the presumption of innocence, puts the burden on the Crown to prove the guilt of an accused by a high degree or quantum of proof that proves the guilt beyond any doubt that a reasonable person can possibly have. $^{54}$ In $R . v$. Lifchus, the Supreme Court of Canada held that a judge must undertake the difficult task of explaining the meaning of reasonable doubt to a jury and instruct them to maintain the presumption of innocence throughout the entire process. ${ }^{55}$

\footnotetext{
${ }^{51}$ The Supreme Court of Canada has repeatedly asserted that the presumption of innocence constitutes an animating principle throughout the criminal justice process. See, $R$ v Pearson, [1992] 3 SCR 320 at para 31.

${ }_{52}$ Mark Heerema, " " ark Heerema, भै Presumption of Factual Innocence in Canadian Law: A Theoretical Model for the "Pre-Charge Presumption of Innocence" (Fall, 2005) 28 Dalhousie LJ 443.

${ }^{53}$ Kent Roach, Criminal Law, $5^{\text {th }}$ ed, (Toronto: Irwin Law, 2012) at 50.

55 The court stated that the idea of reasonable doubt is not an imaginary or frivolous concept, thus, it must not be based upon sympathy or prejudice. Rather, it must be based upon reasoning and commonsense. While the court acknowledged that it will be impossible to prove guilt with $100 \%$ certainty, higher probability or likelihood that an accused has committed the crime is not sufficient for the conviction. The jury must feel that they are sure based on the evidence presented and commonsense that the accused has committed the crime and this is what beyond reasonable doubt means. See Rbe Lifchus, [1997] 3 SCR 320.
} 
It should not be forgotten that the importance of pre-charge and post-charge assumption of innocence are not the same since the aforementioned discussion shows only the significance of post-charge assumption of innocence. However, logically, maintaining the presumption of innocence at pre-charge level is more important because it embodies the normative commitment contained within the criminal justice system to presume that random bystanders are factually innocent; otherwise it will be impossible to live in a society and there will be no faith in humankind. ${ }^{56}$

Requiring an arrestee who is not even charged to provide his bodily samples to put in a permanent DNA database does not conform to this doctrine of presumption of innocence, which is a fundamental value of the Canadian criminal justice system. In R.v. Rodgers, the court found it reasonable to collect DNA samples from the "convicted offenders" because these people were proven to be a threat to society beyond a reasonable doubt. Hence, there was a strong public interest in their identification. However, collecting DNA from arrestees who are neither charged nor proven guilty of a crime or considered a threat to the society crosses any boundary of reasonableness. They could be any random innocent bystanders who happen to be at the wrong place at a wrong time. However, requiring them to provide their bodily samples which contain their most unique and personal information at this stage is another way of making them responsible (at least to some extent) for the crime committed, and makes it seem like they have to prove their innocence. This is a clear violation of their right to be presumed innocent as the Supreme Court of Canada said in $R v$. Whyte that if an accused is required to prove some fact on a balance of probabilities to avoid a conviction, the provision violates the presumption of

\footnotetext{
${ }^{56}$ Mark Heerema, eUncovering the Presumption of Factual Innocence in Canadian Law: A Theoretical Model for the "Pre-Charge Presumption of Innocence" (Fall, 2005) 28 Dalhousie LJ 443.
} 
innocence because it permits a conviction in spite of a reasonable doubt in the mind of the trier of fact as to the guilt of the accused ${ }^{57}$ Consequently, a statute that would permit such infringement will be constitutionally invalid by the virtue of s. 11 (d) of the Charter. The only way such violation could be saved "if the existence of the substituted fact leads inexorably to the conclusion that the essential element exists, with no other reasonable possibilities, will the statutory presumption be constitutionally valid." ${ }^{58}$ However, the mere idea of collecting DNA from arrestees does not fall within this scope of exception and cannot be reasonable.

\section{PART III: JUSTIFICATION UNDER S.1:}

While the Charter guarantees certain rights and freedoms, it also makes it clear that they are not absolute and subject to reasonable limits set out in s. $1{ }^{59}$ Therefore, every claim of Charter rights violation is two folded - (a) whether or not an impugned legislation or government action limits an individual's rights or freedoms set out in the Charter; and (b) if it does, can the limitation be demonstrably justified in a free and democratic society. ${ }^{60}$

Throughout the previous sections, it was established that collecting DNA from arrestees infringes an individualns Charter protected rights and freedoms. Therefore, this section will look at the possibility of whether or not such an infringement could be justified. An important point, to be noted however, is that without having an actual wording and legislative framework, it will be virtually impossible to assess the actual implication and severity of a law that permits an

\footnotetext{
${ }^{57} R v$ Whyte, [1988] 2 SCR 3 at 5.

${ }^{58} R$ v Downey [1992] 2 SCR 10.

${ }^{59}$ It says "to such reasonable limits prescribed by law as can be demonstrably justified in a free and democratic society".

${ }^{60}$ Hogg supra note 5 at $38-1$.
} 
infringement of the Charter. Moreover, it is still not very clear whether an analysis of s. 1 is required in regards to a legislation or government action that violates s. 8 of the Charter. It has been argued that it is redundant to conduct a s.1 analysis when a violation of s. 8 is established because "it is difficult to imagine how an unreasonable search could nevertheless constitute a reasonable limit under section 1" and the reasonable standards that are supposed to make the balance between the state and individual interests are already incorporated within the reasonable standard under s. $8 .{ }^{61}$ On the other hand, Hogg seems to suggest that there still remains a possibility that a law or government action found unreasonable relying on a narrow scale of reasonableness under s. 8 may be found reasonable on a broader scale of reasonableness under s.1. ${ }^{62}$ Nevertheless, DNA collection from arrestees involves more rights than what is protected under s.8. Therefore, this essay will proceed to conducting an analysis of s.1. However, in doing so, only the very idea of DNA collection from arrestees and its possibility of justification under s. 1 of the Charter will be considered.

In $R$ v. Oakes, the Supreme Court of Canada sets out the requirements that must be met in order for an impugned legislation or government actions to be saved under s. $1 .{ }^{63}$ According to the Oakes Test, there are four basic requirements - (1) the law must have an objective that is sufficiently important to justify limiting a Charter right; (2) The law must be rationally connected to the objective; (3) the law must not impair the rights that is no more than necessary to accomplish that objective; and (4) the law must not have a disproportionally severe impact on the person to whom it applies. ${ }^{64}$

\footnotetext{
${ }^{61}$ Steven Penney, Vincenzo Rondinelli \& James Stribopoulos, Criminal procedure in Canada, Student Edition (Markham: Lexis Nexis, 2013) at 207.

${ }_{62}^{62}$ Hogg supra note 5 at 48.

${ }^{63}$ Also known as Oakes Test.

${ }^{64} R v$ Oakes, [1986] 1 SCR 103 at 138-139.
} 
Applying Oakes Test, there is no doubt that collecting DNA from the arrestees has an objective, which is to identify the suspects with better accuracy, something that is important to the criminal justice system. However, this is a very narrow and specified objective and perhaps too narrow to limit some of people's most important rights. This objective will not be rationally connected to the law because there are many other less intrusive ways such as fingerprint and photograph that can be used to identify individuals. As mentioned earlier, DNA can reveal a significant amount of personal information about an individual such as personal genetic make up and core biological information. Collecting this information would not be considered rationally connected to the objective of the law and thus, would infringe more rights than necessary. As a result the collection of DNA would fail to meet first three prongs of the test.

Moreover, as it is apparent from the previous discussion that collecting DNA is a highly intrusive process that involves bodily integrity and infringes some of the most fundamental rights, the violation cannot be minimal on a balance of probability. In justifying the DNA collection from arrestee in Maryland v. King, the Supreme Court of the United States holds that "the arrestee is already in valid police custody for a serious offense supported by probable cause. ${ }^{65}$ "The court went as far as saying that the arrestee has a reduced privacy interest because he or she has "been suspected of a wrong". ${ }^{66}$ However, if merely for the purpose of identification, it becomes necessary to collect DNA samples from people who are presumed to be innocent and not yet proven to be a threat for the society, then logically, it will also be justified to collect DNA evidence in every situation, which requires a person to identify him or herself (i.e. stopping a vehicle for speeding, accessing government facilities, entering to court

\footnotetext{
${ }^{65}$ Maryland supra note 1 at 9.

${ }^{66} \mathrm{Ibid}$ at 25.
} 
rooms etc.). A free and democratic society cannot afford to extend the scope of privacy infringement to such an extent, especially by a government, which always has a serious interest in limiting individualsto extend the scope of

Finally, a legislation permitting collection of DNA from arrestees would disproportionally impact not only the person to whom it applies but also the society as a whole. First of all, collecting DNA from an individual and entering it in a national DNA database may create a psychological prison for the person. A person would not know how much information about him or her is in the hand of government and how the information will be handled. He or she would constantly worry about the potential misuse of the information as the database is humanly operated and the information is vulnerable to abuse, misinterpretation and distortion. Also, the fact that the conviction rate of violent crimes in Canada is very low $(52 \%)$, it means that almost half of the people whose rights and liberties will be taken away and be psychologically imprisoned are actually not criminals. ${ }^{67}$

Allowing warrantless DNA collection of arrestees will disproportionately impact the members of visible minority ${ }^{68}$ and socially disadvantaged groups such as Aboriginal and Black communities. They will be unduly impacted because it is an open secret that the "Black community is subject to much greater police surveillance", and "much more likely to be caught when they break the law compared to White people who engage in the same forms of criminal activity". ${ }^{69}$ While it is very difficult to find actual statistic of racial arrests in Canada, as there is no requirement to record an arresteecret that the "Black community is subject to much greater

\footnotetext{
${ }^{67}$ In $2010 / 11$, only $52 \%$ of violent-crime cases resulted in guilty rulings, $40 \%$ were stayed or withdrawn and $6 \%$ ended in acquittals. See, Mia Dauvergne, Adult criminal court statistics in Canada, 2010/2011, Online: Statistics Canada <http://www.statcan.gc.ca/pub/85-002-x/2012001/article/11646-eng.htm>

${ }^{68}$ Stuart supra note 45 at 1134.

${ }^{69}$ Scot Wortley and Julian Tanner, Discrimination or ,Good"oPolicing? The Racial Profiling Debate in Canada, online: Metropolis, <http://canada.metropolis.net/pdfs/WortleyTanner_e.pdf>.
} 
police surveillance", and "much more likely to be caught when they black drug dealers (selfidentified) report that they have been arrested at some time in their lives, compared to only $35 \%$ of the White drug dealers (self-identified)". ${ }^{70}$ Therefore, a significant numbers of people in the government DNA database would be the members of visible minority groups. Consequently, they will be more vulnerable to many different forms of discrimination, police suspicions and socio-legal marginalization.

\section{CONCLUSION:}

In conclusion, it is clear that although DNA collection might be a useful identification tool for law enforcement, it can reveal some of the most unique and biographical core of personal information about an individual that should not be under the possession of the government without prior judicial authorization based on probable cause. A search of arrestees that includes DNA collection without their consent or a valid warrant will always infringe on their right to reasonable expectation of privacy and deprive them from their right to be presumed innocent before proven legally and factually guilty. A statue that authorizes such a search will not meet the requirements and standards of reasonableness established by the Canadian courts and cannot be justified in a free and democratic society.

\section{Bibliography}

\section{Jurisprudence:}

Hunter v. Southam Inc, [1984] 2 SCR 145.

\footnotetext{
${ }^{70}$ Ibid.
} 
Maryland v King, [2013] US LEXIS 4165.

$R v$ Alderton, [1985] 49 OR (2d) 257 (CA).

$R v$ Belnavis, [1997] 3 SCR 341.

$R v$ Downey [1992] 2 SCR 10.

$R$ [1992] $2 S$ [1996] 1 SCR 128.

$R v$ Feeney, [1997] 2 SCR 117.

$R v$ Grants, [2009] 2 SCR 353.

R00 Lifchus, [1997] 3 SCR 320.

$R$ v Oaks, [1986] 1 SCR 103.

$R v$ Plant, [1993] 3 SCR 281.

$R v$ Pohoretsky [1987] 1 SCR 945.

$R v$ Pearson, [1992] 3 SCR 320.

$R v$ Rao (1984), 46 OR (2d) 80 (CA).

$R v$ Stillman, [1997] 1 SCR 607.

$R v$ Tessling [2004] 3 SCR 432.

$R v$ Whyte, [1988] 2 SCR 3.

\section{Legislation:}

Canadian Charter of Rights and Freedoms, Part I of therConstitution Act, 1982, being Schedule B to thesCanadag Schedul anadag Schedule B

Canadian Criminal Code RSC, 1985, c C-46.

DNA Fingerprint Act, 42 US, Code $\$ 214135 \mathrm{a}$.

DNA Identification Act, SC SCIdentifi

\section{Books:}

Bereano, PL. "The Impact of DNA-based Identification Systems on Civil Liberties" in Billings, ed DNA on Trial: Genetic Identification and Criminal Justice (New York: Cold Spring Harbor Laboratory Press, 1992). 
Cromwell, Thomas. "Proving Guilt: The Presumption of Innocence and the Canadian Charter of Rights and Freedoms" in William H Charles, Thomas A Cromwell \& Keith B Jobson eds, Evidence and the Charter of Rights and Freedoms (Toronto: Butterworths, 1989).

Hogg, Peter. Constitutional Law of Canada, loose-leaf (Toronto: Carswell, 2006).

Penney, Steven, Rondinelli, Vincenzo, \& Stribopoulos, James, Criminal procedure in Canada, Student Edition (Markham: Lexis Nexis, 2013) at 207.

Roach, Kent. Criminal Law, $5^{\text {th }}$ ed, (Toronto: Irwin Law, 2012).

\section{Journals, Reports and Online Sources}

Ahmed, Washim. "hmed, Washim. ts and Online Sources James, opoulos, James, e and the Canadian Chart (August 16, 2013), online: Social Science Research Network $<\mathrm{http}: / /$ ssrn.com/abstract $=2508804>\mathrm{tt}$

Canada, Solicitor-General of Canada, Establishing a National DNA Data Bank (Consultation Paper) (Ottawa: Ministry of Supply and Services, 1996).

Dauvergne, Mia, Adult criminal court statistics in Canada, 2010/2011, Online: Statistics Canada <http://www.statcan.gc.ca/pub/85-002-x/2012001/article/11646-eng.htm>.

Drobner, FW. "DNA Dragnets: Constitutional Aspects of Mass DNA Identification Testing" (2000), 28 Cap UL Rev 479.

Heerema, Mark, Uncovering the Presumption of Factual Innocence in Canadian Law: A Theoretical Model for the "Pre-Charge Presumption of Innocence" (Fall, 2005) 28 Dalhousie LJ 443.

Juengst, ET. "I-DNA-fication, Personal Privacy, and Social Justice" (1999), 75 Chi-Kent L Rev 61.

MJ, Markett."Genetic Diaries: An Analysis of Privacy Protection in DNA Data Banks" (1996), 42 Case W Res L Rev 635.

Mackrael, Kim. Feds looks at plan to collect DNA from suspects upon arrest, The Glove and Mail (2 October 2013) online: $<$ http://www.theglobeandmail.com/news/politics/ottawa-looks-at-plan-tocollect-dna-from-suspects-upon-arrest/article14652881/>.

Parfett, Julianne, “ lianne, , ianne, nline: <http://www.theglobeandmail.co, (2002) 29 Man LJ 33. 
Scot Wortley and Julian Tanner, Discrimination or ,Good"oPolicing? The Racial Profiling Debate in Canada, online: Metropolis, $<$ http://canada.metropolis.net/pdfs/WortleyTanner_e.pdf $>$.

Stuart, Brian, oDethroning King: Why the Warrantless DNA Testing of Arrestees Should Be Prohibited Under State Constitutions (2014) 88 Missisipi LJ 1111.

US Congress, Office of Technology Assessment, Genetic Witness: Forensic Uses of DNA Tests, OTA-BA-438 (Washington: US Government Printing Office, July 1990). 